\title{
History of views on the relative positions of Antarctica and South America: A 100-year tango between Patagonia and the Antarctic Peninsula
}

\section{H. Miller}

Department of Geo- and Environmental Sciences, Ludwig-Maximilians-Universität, 80333 München, Luisenstr. 37, Germany (h.miller@lmu.de)

Abstract Discussion of continental drift around Antarctica began nearly 100 years ago. While the Gondwana connections of Antarctica to Africa and Australia have been well defined for decades, the relative pre-drift positions of the Antarctic Peninsula and Patagonia continue to be subjects of controversy. Certainly older figures, which showed a paleo-position of the Peninsula crossing over continental crust of the Falkland Plateau or even South Africa or Patagonia, are out of consideration now. But contradictory opinions remain over the relative paleo-position of the Peninsula as a more or less straight prolongation of the Patagonian Andes, versus a position parallel to Patagonia along the Pacific coast. Geological reasons are found for both opinions, but geophysical observations on the adjacent ocean floors, particularly the evolution of the Weddell Sea crust, speak for the last-mentioned reconstruction.

Citation: Miller, H. (2007), History of views on the relative positions of Antarctica and South America: a 100-year tango between Patagonia and the Antarctic Peninsula, in Antarctica: A Keystone in a Changing World - Online Proceedings of the $10^{\text {th }}$ ISAES, edited by A.K. Cooper and C.R. Raymond et al., USGS Open-File Report 2007-1047, Short Research Paper 041, 4 p.; doi:10.3133/of2007-1047.srp041

\section{Introduction}

Antarctica has been called "the heart of Gondwana" with reason: it is the only continent that had immediate contact to all other members of the Gondwana family. Campbell Craddock (1970) was the first to present a colored reconstruction of Antarctica within Gondwana. For the relation to South America via the Scotia arc (Fig. 1) he followed Du Toit's (1937) Samfrau geosyncline figure.

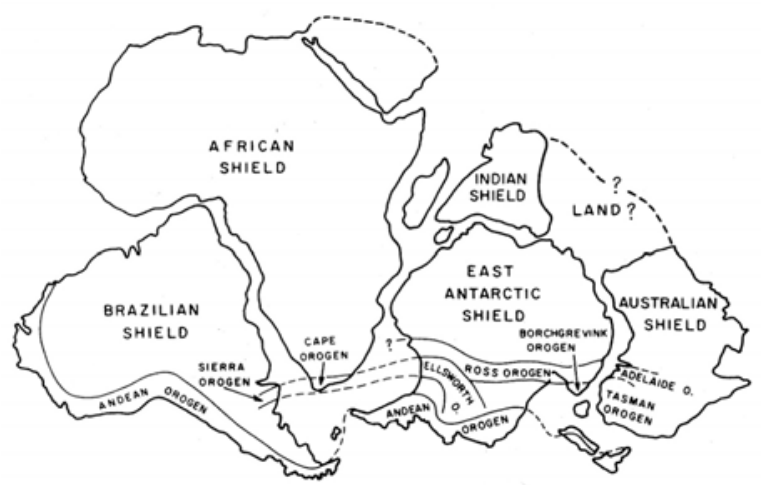

Figure 1. Gondwana reconstruction made by Craddock (1982). As in Du Toit (1937), the Peninsula lies close to Africa to avoid super-imposition over the Falkland Plateau. From Craddock (1982), Craddock, J. Campbell. ANTARCTIC GEOSCIENCE. (C) Reprinted by permission of The University of Wisconsin Press.

The relations of the Antarctic Peninsula and adjacent islands to the close lying southern tip of South America (Patagonia) have been argued up to now. This resulted in a multitude of comparative presentations in the 1970s and early 1980s (e. g. Dalziel and Elliot, 1971; Dalziel, 1982; Ford, 1972). The manifold attempts referring to the relation between the Antarctic Peninsula and other continents, will be grouped together and discussed in a general way, narrating the story of the "Peninsula Patagonia tango".

\section{The tango figures}

\section{First attempts}

Alfred Wegener ( $4^{\text {th }}$ edition, 1929) and his forerunner Taylor (1910) did not endeavor much to solve the problem - too little facts were known about it. In Wegener's simplistic draft, West Antarctica and the Peninsula bordered more or less on the straight prolongation of Patagonia. On the contrary, Baker (1911; taken from Du Toit, 1937) was the first to consider in detail a rather strange position of the Peninsula pointing to Australia (Fig. 2).

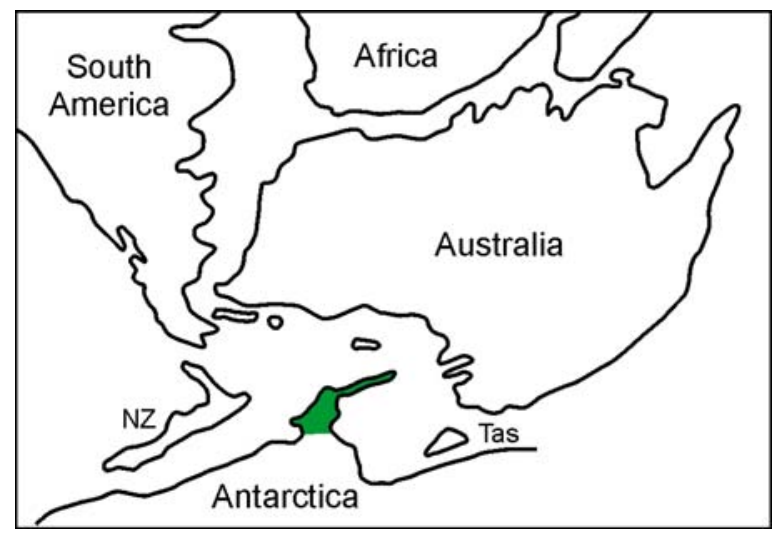

Figure 2. Gondwana reconstruction by Baker (1911; taken from Du Toit, 1937).

\section{The Antarctic Peninsula east of Patagonia}

In the infancy of reconstructions, the Peninsula was often positioned east of Patagonia (Fig. 3). This resulted in an overlap with the continental crust that links Patagonia with the Falkland (Malvinas) Islands, even with South Africa or South America. As then most rocks of the 
Peninsula were considered Mesozoic and younger, many authors were sympathetic to this graphic overlap (Fig. 4 b, e. g. Smith and Hallam, 1970; Dietz et al., 1972; Norton, 1982).

Nowadays, the crust of the Peninsula is definitely regarded as old and continental (e. g. Millar et al., 2002). Consequently, the Peninsula cannot be placed

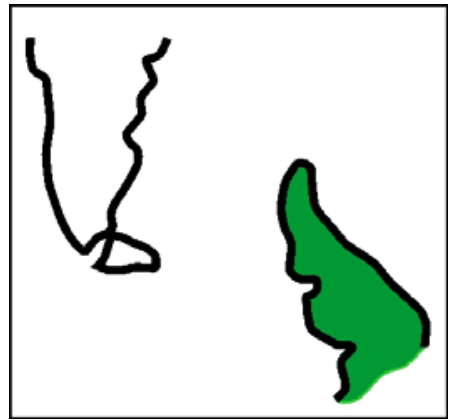

Figure 3. Peninsula immediately east of Patagonia.

immediately east of Patagonia. Du Toit (1937) and Craddock (1970, 1982) assumed the Peninsula to be far off Patagonia and Tierra del Fuego, close to Africa, to avoid an overlap with the Falkland Plateau (Fig. 1), whereas Dalziel (1982) for a time put the Peninsula just along the East Antarctic shield (Fig. 4 a).
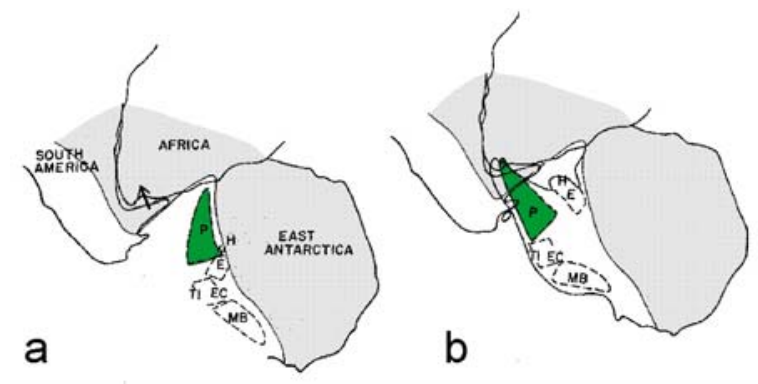

Figure 4. a). Peninsula adjacent to East Antarctica, to avoid superimposition to Falkland Plateau and South Africa. b). Peninsula crossing the Falkland Plateau and entering South Africa. Slightly modified from Dalziel (1982), Craddock, J. Campbell. ANTARCTIC GEOSCIENCE. (C) Reprinted by permission of The University of Wisconsin Press.

The Antarctic Peninsula as a straight prolongation of the Andes

At a glance, the simplest pre-drift connection between Patagonia and the Antarctic Peninsula is the straight line between both parts (Fig. 5). Such pre-Jurassic position was described in detail by Suárez (1976). The opinion was propagated particularly by geologists of the British Antarctic Survey in the 1970s and 1980s (e.g. Elliot, 1972; Storey, 1991; Doyle and Whitham, 1991). As much as it appears to be plausible, this reconstruction is failing to explain some facts:
On the Peninsula, prograding Mesozoic turbidites occur (Hervé et al., 2006 a, and references herein) with variable Paleozoic and Mesozoic detrital zircon ages (Millar et al., 2001; Hervé et al., 2006 a, b). Where are these sediments coming from, if not from a continent in the east? Which was this continent, if there actually was a sort of paleo-Weddell Sea?

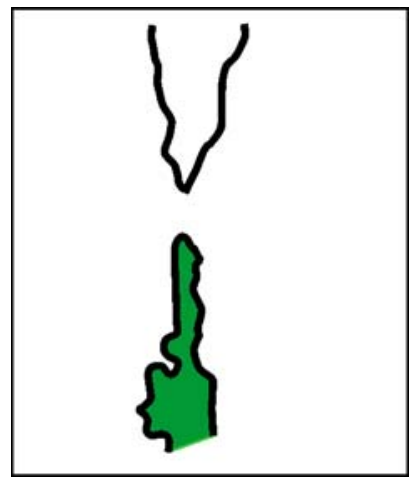

Figure 5. Peninsula as a straight prolongation of Patagonia, as considered by Wegener (1929) and by many authors of the 1970s and early 1980s.

\section{The Antarctic Peninsula at the western flank of Patagonia}

An extreme northerly position of the Peninsula parallel to Patagonia ("long-legged tango", Fig. 6 a) was preferred by Harrison et al. (1979) and Wilson et al. (1989). This position is in best accordance with the prograding sedimentation and folding at the Pacific border of Gondwana (Miller, 1983) as well as with sandstone detrital modes (Willan, 2003). It corresponds with the geomagnetic data of the Weddell Sea ocean floor (e. g. Ghidella et al., 2002; König and Jokat, 2006). Following paleo-magnetic research in West Antarctica, also DiVenere et al. (1996) understood the Peninsula to have been situated parallel to Patagonia.

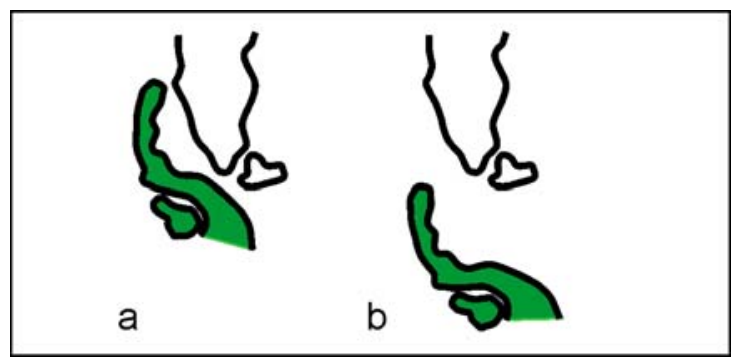

Figure 6. a) Peninsula adjacent to Patagonia at its Pacific rim. b) Northern tip of the Peninsula along Tierra del Fuego.

The post-Jurassic movement of the Peninsula towards its present-day position, in this case, should have been left-lateral. Wilson et al. (1989) outlined such left-lateral transform fault in their 100 Ma ago sketch. 
A position of the tip of the Peninsula west of Tierra del Fuego ("short-legged tango", Fig. 6 b) has been used frequently (e. g. Pankhurst et al., 2000; Dalziel and Lawver, 2001). This explanation combines some of the afore mentioned arguments for a straight line continuation of the Patagonian Cordillera to the Peninsula with the requirement of a continent next to it that was suitable for delivering Paleozoic detritus.

\section{Discussion and conclusions}

A final statement on the exact pre-drift position of the Antarctic Peninsula relative to Patagonia is not easy at present. It is noteworthy that the opinions deriving from ocean bottom paleomagnetism generally defend a "longlegged tango" figure while the geological arguments often prefer a "short-legged" one or a just straight continuation between both parts of continental crust.

The major problem is how to harmonize the geological facts, e.g. the basin evolution at the Weddell Sea coast of the Peninsula (Doyle and Whitham, 1991; Hunter and Cantrill, 2006), with the paleomagnetic data of the Weddell Sea spreading history. The function of the "Rocas Verdes Basin" in southern Patagonia (Dalziel et al., 1974; Suárez, 1976) as a precursor of the Weddell Sea should be considered in this context. For the intent to merge both views, the recent study of König and Jokat (2006) is helpful.

The authors show that the separation of Patagonia and the Antarctic Peninsula is not only a simple gliding along a transform fault (as suggested e.g. by Hervé et al. (2006 a), but began with the opening of a wide extensional basin. The reconstructions of König and Jokat (2006, Figs. 11, 12) allow to transport siliciclastic sediments from South America to the Antarctic Peninsula from Triassic to Cretaceous times along the joint Patagonia/Antarctic Peninsula west coast.

At the same time, a wide shelf area existed around the Rocas Verdes Basin in western Patagonia from Jurassic to Cretaceous, which may have been the area of deposition of the Mesozoic continental and marine sedimentary rocks of the east coast of the Antarctic Peninsula. A comparison of the Mesozoic marine evolution of east (Atlantic side) Patagonia and the Antarctic Peninsula is not necessary in this case. The Jurassic acidic volcanism described by Pankhurst et al. (2000) from southern Patagonia as well as from the Antarctic Peninsula can be interpreted as a contemporary magmatic event on continental crust at both sides of the oceanic "Rocas Verdes Basin".

The manifold terrane accretions at both the Pacific margins of Patagonia (Hervé et al., 2006 a) and the Antarctic Peninsula (e.g. Vaughan and Storey, 2000) play an important role in this puzzle, the strike-slip movements in between several units of the Peninsula (Smith Island and Elephant Islands) included. As in the past, for solving those remaining queries, new facts, close discussion with scientists from all branches of geosciences, and new fantasy are needed.
Acknowledgements. The author thanks the co-editor Wesley LeMeasurier, and the reviewers David Elliot and Wilfried Jokat for valuable hints for improving the manuscript.

\section{References}

Craddock, C. (1970), Tectonic map of Gondwana, in Geologic maps of Antarctica, edited by V. C. Bushnell, and C. Craddock, Antarctic Map Folio Series, Folio 12, plate XXIII, Amer. Geogr. Soc., New York.

Craddock, C. (1982), Antarctica and Gondwanaland, in Antarctic Geoscience, edited by C. Craddock, pp. 3-13, Univ. of Wisconsin Press, Madison Wisc.

Dalziel, I. W. D. (1982), The early (pre-middle Jurassic) history of the Scotia Arc region. A review and progress report, in Antarctic Geoscience, edited by C. Craddock, pp. 111-126, University of Wisconsin Press, Madison.

Dalziel, I. W. D., and D. H. Elliot (1971), Evolution of the Scotia Arc, Nature, 233, 246-252.

Dalziel, I. W. D., M. J. de Wit, and K. F. Palmer (1974), Fossil marginal basin in the southern Andes, Nature, 250, 291-294.

Dalziel, I. W. D., and L. A. Lawver (2001), The lithospheric setting of the West Antarctic ice sheet, in The west Antarctic ice sheet: behaviour and environment, Antarctic Res. Ser. 77, pp. 29-44, Amer. Geophys. Union.

Dietz, R. R., J. C. Holden, and W. P. Sproll (1972), Antarctica and continental drift, in Antarctic geology and geophysics, edited by R. J. Adie, pp. 837-847, Universitetsforlaget, 1972.

DiVenere, V. J., D. V. Kent, and I. W. D. Dalziel (1996), Summary of palaeomagnetic results from West Antarctica: implications for the tectonic evolution of the Pacific margin of Gondwana during the Mesozoic, in Weddell Sea tectonics and Gondwana Break-up, edited by B. C. Storey, E. C. King, and R. A. Livermore, Geol. Soc. Spec. Publ., 108, pp. 31-43.

Doyle, P., and A. G. Whitham (1991), Palaeoenvironments of the Nordenskjöld Formation: an Antarctic Late Jurassic - Early Cretaceous black shale-tuff sequence, in Modern and Ancient Continental Shelf Anoxia, edited by R. V. Tyson, and T. H. Pearson, Geol. Soc Spec. Publ., 58, pp. 397-414.

Elliot, D. H. (1972), Aspects of Antarctic geology and drift reconstructions, in Antarctic geology and geophysics, edited by R.A. Adie, pp. 849-858, Universitetsforlaget, Oslo.

Ford, A. B. (1972), Fit of Gondwana continents - Drift reconstruction from the Antarctic continental viewpoint, in $24^{\text {th }}$ Internat. Geol. Congr., section 3, edited by J. E. Gill, pp. 113-121, Montreal.

Ghidella, M. E., G. Yáñez, and J. L. LaBrecque (2002), Revised tectonic implications for the magnetic anomalies of the Western Weddell sea, Tectonophysics, 347, 65-86.

Harrison, C. G. A., E. J. Barron, and W. W. Hay (1979), Mesozoic evolution of the Antarctic Peninsula and the southern Andes, Geology, 7, 374-378.

Hervé, F., H. Miller, and Ch. Pimpirev (2006 a), Patagonia - Antarctica connections before Gondwana break-up, in Antarctica: Contributions to global earth sciences, edited by D.K. Fütterer, D. Damaske, G. Kleinschmidt, H. Miller, and F. Tessensohn, pp. 217-228, Springer, Berlin.

Hervé, F., V. Faúndez, M. Brix, and M. Fanning (2006 b), Jurassic sedimentation of the Miers Bluff Formation, Livingston Island, Antarctica: evidence from SHRIMP U-Pb ages of detrital and plutonic zircons, Antarctic Sci., 18, 229-238.

Hunter, M. A., and D. J. Cantrill (2006), A new stratigraphy for the Latady Basin, Antarctic Peninsula: part 2, Latady Group and basin evolution, Geol. Mag., 143, 797-819.

König, M., and W. Jokat (2006), The Mesozoic breakup of the Weddell Sea, J. Geophys. Res., 111, B12102, doi: 10.1029/2005JB00435.

Millar, I. L., R. J. Pankhurst, and C. M. Fanning (2002), Basement chronology of the Antarctic Peninsula: recurrent magmatism and anatexis in the Palaeozoic Gondwana margin, J. Geol. Soc. London, 159, 145-157.

Millar, I. L., R. J. Pankhurst, A. P. M. Vaughan, and C. M. Fanning (2001), Exotic crustal fragments on the Pacific margin of Gondwana, III South Amer. symp. isotope geol., extended abstr. vol. (CD), 589592, Soc. Geol. Chile, Santiago, Chile. 
Miller, H. (1983), The position of Antarctica within Gondwana in the light of Palaeozoic orogenic development, in Antarctic Earth Science, edited by R. L. Oliver, P. R. James, and J. B. Jago, pp 579-581, Australian Academy of Sciences, Canberra.

Norton, I. O. (1982), Paleomotion between Africa, South America, and Antarctica, and implications for the Antarctic Peninsula, in Antarctic Geoscience, edited by C. Craddock, pp. 99-106, Univ. of Wisconsin Press, Madison, Wisc.

Pankhurst, R. J., T. R. Riley, C. M. Fanning, and S. P. Kelley (2000), Episodic silicic volcanism in Patagonia and the Antarctic Peninsula: Chronology of magmatism associated with the break-up of Gondwana, J. Petrology, 41, 605-623.

Smith, J. L., and A. Hallam (1970), The fit of the southern continents, Nature, 225, 139-144.

Storey, B.C. (1991), The crustal blocks of West Antarctica within Gondwana: reconstruction and break-up model, in Geological Evolution of Antarctica, edited by M. R. A. Thomson, J.-A. Crame , and J. W. Thomson , pp. 587-592, Cambridge University Press, Cambridge.

Suárez, M. (1976), Plate-tectonic model for southern Antarctic Peninsula and its relation to southern Andes, Geology, 4, 211-214.

Taylor, F. B. (1910), Bearing of the Tertiary mountain belt on the origin of the Earth's plan, Bull. Geol. Soc. Amer., 21, 179-226.

Toit, A.L. du (1937), Our wandering continents, 366 pp., Oliver and Boyd, Edinburgh.

Vaughan, A. P. M., and B. C. Storey (2000), The Eastern Palmer Land shear zone: a new terrane accretion model for the Mesozoic development of the Antarctic Peninsula, J. Geol. Soc. London, 157, 1243-1256.

Wegener, A. (1929), Die Entstehung der Kontinente und Ozeane, $4^{\text {th }}$ edition, 231 S., Vieweg, Braunschweig.

Willan, R. C. R. (2003), Provenance of Triassic-Cretaceous sandstones in the Antarctic Peninsula: Implications for terrane models during Gondwana breakup, J. Sediment. Res., 73, 1062-1077.

Wilson, K. M., M. J. Rosol, W. W. Hay, and Ch. G. A. Harrison (1989), New model for the tectonic history of West Antarctica: a reappraisal of the fit of Antarctica in Gondwana, Eclogae geol. Helv., 82, 1-35. 